\title{
Differential expression of somatostatin receptor subtype-related genes and proteins in non-functioning and functioning adrenal cortex adenomas
}

\author{
HANNA PISAREK ${ }^{1}$, ROMAN KRUPIŃSKI ${ }^{4}$, ROBERT KUBIAK ${ }^{2}$, EDYTA BORKOWSKA ${ }^{3}$, \\ MAREK PAWLIKOWSKI ${ }^{1}$ and KATARZYNA WINCZYK ${ }^{1}$
}

Departments of ${ }^{1}$ Neuroendocrinology, ${ }^{2}$ Pathology of Tumors, and ${ }^{3}$ Medical Genetics, Medical University of Łódź;

${ }^{4}$ Clinic of Endocrinological and General Surgery, Copernicus Hospital, Łódź, Poland

Received February 14, 2011; Accepted June 6, 2011

DOI: $10.3892 / \mathrm{mmr} .2011 .519$

\begin{abstract}
Adrenocortical adenomas display highly variable expressions of somatostatin receptor (SSTR) subtypes, whose expression is mandatory (although not always sufficient) to achieve the positive effects of somatostatin (SST) analog therapy. Immunohistochemistry (IHC) is the main method used to investigate receptor protein expression. The molecular biology method - polymerase chain reaction (PCR) - is also often used to investigate receptor expression. Nevertheless, the expression of receptor mRNA and the respective receptor protein is not always synchronized. The aim of this study was to investigate SSTR expression by IHC in adrenal adenomas, to compare the results to data obtained by real-time PCR and to determine whether hormonally functioning and nonfunctioning adenomas differ in this respect. Adrenocortical adenomas were removed surgically from 13 females and 2 males. The tissues were obtained from 9 non-functioning and 6 functioning adenomas. The intensity of IHC reaction was scored semiquantitatively by two independent observers. Real-time PCR was performed using pairs of primers in a reaction amplified along a gradient of temperatures. Amplified DNA was measured by monitoring SYBR-Green fluorescence. In non-functioning tumors, compatibility between IHC and PCR results was observed for SSTR 1 and 2 in $62.5 \%$ of the samples. Fifty percent of patients demonstrated compatibility for SSTR 4 and 5 and 37.5\% for SSTR 3. In hormonally active adenomas, total compatibility of both methods was noted for SSTR 2 (100\%). The compatibility obtained for SSTR 5 was $66.6 \%$. We conclude that receptor gene and respective receptor protein expression are not always synchronized. Messenger RNA detection alone is not sufficient to predict the presence of the receptor protein acting as a target for SST and its analogs.
\end{abstract}

Correspondence to: Dr Hanna Pisarek, Department of Neuroendocrinology, Medical University of Łódź, Sterling str. 3, Łódź 91-425, Poland

E-mail: hanna.pisarek@umed.lodz.pl

Key words: somatostatin receptor subtypes, adrenal cortex adenomas

\section{Introduction}

It has been documented that adrenal gland tumors are relatively common and constitute 5-9\% of all human tumors $(1,2)$. The majority of them are of adrenocortical origin and most frequent in the population are adrenocortical adenomas with or without hormonal activity (3). The adrenal gland is known as a target organ for somatostatin (SST) and receptors for this neuropeptide [somatostatin receptors (SSTRs)] have been identified in physiological as well as in pathological conditions (4-6). Despite several studies, the data concerning the occurrence of SSTRs in human adrenal gland tumors often present different conclusions depending on the investigation method used (7-11). Therefore, the authors agree that there is a highly variable expression of SSTR subtypes in adrenocortical adenomas. It is difficult to state for certain which receptor subtype is dominant in this type of endocrine tumors. SSTRs mediate the antiproliferative (12-14), anti-angiogenic and pro-apoptotic actions (15-18) of SST and its analogs, and their expression is a mandatory (although not always sufficient) part of successful SST analog therapy.

Immunohistochemistry (IHC) is the main method used to investigate the expression of the receptor protein as a real target for SST and its analogs. It uses highly specific polyclonal antibodies to detect SSTR subtypes and its results represent the total amount of immunoreactive receptor protein. Additionally, in contradistinction to Western blotting experiments, this method provides insight into the cellular distribution of the receptor protein. Additionally, molecular biology methods, in particular the polymerase chain reaction (PCR), are also often used to investigate receptor expression. These methods give results at the mRNA level. However, the expression of mRNA and its respective protein are not always required to be synchronized $(19,20)$, as post-transcriptional defects or modifications occur that cause protein translation to be inhibited (19). Such a situation has already been observed during our investigation of SSTR expression in thyroid gland tumors, where discrepancies were noted between the results of both techniques (21).

Previously, we reported the distribution of all five subtypes of SSTR (including 2A and 2B isoforms) in various adrenal 
tumors (22). In this study, IHC was used to investigate SSTR expression in adrenal adenomas and to compare the results to data obtained by a molecular biology method, such as realtime PCR.

\section{Materials and methods}

This project received the approval of the Ethics Committee of the Medical University of Łódź, no. RNN/97/06/KE. Samples of adrenocortical adenomas were received from 15 patients operated on in our Department of General and Endocrine Surgery during 2010. This group consisted of 13 females and 2 males, aged between 35-74 years (mean, 58.4). The tissues were obtained from 9 clinically non-functioning adenomas ( 7 females and 2 males, aged between $48-74$ years, mean, 59.7) and 6 functioning adenomas from 6 females aged 35-74 years, mean, 56.5 (3 with primary hyperaldosteronism and 3 with ACTH-independent Cushing's syndrome). The diameters of removed adenomas ranged between 0.7 and $5 \mathrm{~cm}$. Histopathological examinations revealed all of them to be adrenal adenomas with a mitotic index of 0/20 HPF.

$I H C$. The tissue samples were fixed in $10 \%$ formalin and paraffin-embedded. Immunohistochemical examination of SSTR subtypes was performed as previously described by Schulz et al (23), using commercially available rabbit polyclonal antisera raised against carboxyl-terminal fragments of specific human SSTR subtypes, including SSTR 2A and SSTR 2B isoforms (GRAMSCH Laboratories, Schwabhausen, Germany): SSTR 1 (named SS-840 antibody, corresponding to amino acid sequence $377-391$ of the receptor peptide chain), SSTR 2A (SS-800, specific for 355-369 sequence), SSTR 2B (SS-860, specific for 342-356 sequence), SSTR 3 (SS-850, specific for 381-395 sequence), SSTR 4 (SS-880, specific for 374-388 sequence) and SSTR 5 (SS-890, specific for 350-364 sequence).

Following overnight incubation at $4^{\circ} \mathrm{C}$ in a humidified chamber with primary antibodies (dilution 1:1000 in $0.05 \mathrm{M}$ TRIS buffer, $\mathrm{pH} 7.6$, containing $2 \%$ goat serum), the cells were treated with anti-rabbit IgG biotinylated goat antibody (dilution 1:800; Dako, Denmark) and streptavidin complex (Strept ABC/HRP; Dako). The immunoreaction was visualized with 3.3'-diaminobenzidine (DAB; Dako) solution. For the negative control, the primary antibody was omitted and normal goat serum was used. At least six sections were examined per tumor. The intensity of immunoreaction for specific receptor proteins was scored semiquantitatively by two independent observers using a descriptive scale as follows: Marked staining (score, 3.00), moderate staining (score, 2.00), weak staining (score, 1.00) and trace staining (score, 0.50). A marked staining was defined as displaying maximal intensity of immunoreaction observed in the investigated material; moderate, as the average intensity observed; and weak, as the weakest intensity still considered as undoubted positive reaction. The mean scores obtained from both investigators were calculated. Those results with scores of at least 2.00 were taken into further consideration.

Real-time PCR. Total RNA was isolated from $1 \mathrm{~g}$ of frozen tissue from 14 patients using the Magna Pure Compact
RNA Isolation kit (Roche Molecular Biochemicals Cat. No. 04802993 001). Total RNA was DNase-treated using DNase I (RNase free) reagent (Ambion Cat. No. AM2222). First-strand cDNAs were synthesized from equal amounts of total RNA (0.5 $\mu \mathrm{g} /$ reaction) using oligo(dT) and the iScript cDNA Synthesis kit (Bio-Rad Cat. No. 70-8890) according to the manufacturer's instructions. All primers were purchased from Oligo PAN, Warsaw, Poland (Table I). RT-PCR was performed using pairs of primers in a reaction amplified across a gradient of annealing temperatures to identify optimal reaction conditions. The iCycler iQ System (BioRad Cat. No. 170-8701, 170-9750) was used for the reaction. The rate of accumulation of amplified DNA was measured by continuous monitoring of SYBR-Green I fluorescence. A melt curve of the reaction products was generated in each experiment.

In particular, quantitative real-time PCR on the iCycler iQ was performed in triplicate on $1 \mu \mathrm{l}$ of template cDNA per $25 \mu \mathrm{l}$ reaction. iQ supermix reactions consisted of iQ SYBR-Green Supermix (Bio-Rad Cat. No. 70-8882) at a final concentration of $1 \mathrm{X}, 10 \mathrm{nM}$ fluorescein calibration dye, SYBR-Green I and $500 \mathrm{nM}$ of each primer. Reactions were amplified in a 96-well thin-wall PCR plate (Bio-Rad Cat. No. 223-9441) using the following PCR parameters: $95^{\circ} \mathrm{C}$ for $3 \mathrm{~min}$ followed by 50 cycles of $95^{\circ} \mathrm{C}$ for $10 \mathrm{sec}, 60^{\circ} \mathrm{C}$ for $30 \mathrm{sec}$ and $72^{\circ} \mathrm{C}$ for $30 \mathrm{sec}$. Melt-curve analysis was performed immediately following amplification by increasing the temperature in $0.4^{\circ} \mathrm{C}$ increments starting at $60^{\circ} \mathrm{C}$ for 85 cycles of $10 \mathrm{sec}$ each. The presence of a single PCR product was verified by the presence of a single melting temperature peak.

Real-time RT-PCR reactions for the detection of the endogenous control gene [hypoxanthine-guanine phosphoribosyltransferase (HPRT)] were run in parallel with each experimental run as a reference for sample dilution accuracy. The result for the endogenous control gene (HPRT) was treated as negative (score, 0.000) and according to this, all remaining mRNAs were calculated relative to the amount of HPRT and given in arbitrary units (expression). Positive results of subtype-specific mRNA expression with values of $\geq 1.000$ were taken into further consideration.

For each experiment, the 3-point standard curve was performed with commercial control RNA [Applied Biosystems Control Total RNA Human 4307281 (100 $\mu 1$ concentrate 50 ng/ $\mu 1)$ - dilution $\mathrm{x} 1, \mathrm{x} 10$ and $\mathrm{x} 100]$.

\section{Results}

IHC was performed on 15 samples, while RT-PCR was performed on 14 as the mRNA isolation failed in 1 sample (no. 3). SSTR subtypes 2A and 2B present two splicing variants and differ only in the length of their cytoplasmic tail. They are coded by the same gene (SSTR 2), thus molecular analysis concerned only one SSTR 2 mRNA. Therefore, the immunohistochemical results for each isoform alone were also presented as the mean value of scores, $2 \mathrm{~A}$ and 2B. Only the cytoplasmic immunostaining was taken into consideration in estimating the level of receptor protein expression. SSTR scores were compared between nonfunctioning and functionally active adenomas. It should be pointed out that multiple SSTR subtypes coexisted in each 
Table I. Primer sequences applied for quantitative real-time PCR.

\begin{tabular}{|c|c|c|c|}
\hline Name & Sequence & Size of PCR product (bp) & GenBank accession no. \\
\hline SSTR 1 (forward) & 5'-TATCTGCCTGTGCTACGTGC-3' & \multirow[t]{2}{*}{$217(25)$} & \multirow[t]{2}{*}{ NM 001049} \\
\hline SSTR 1 (reverse) & 5'-GATGACCGACAGCTGACTCA-3' & & \\
\hline SSTR 2A (forward) & 5'-ATGCCAAGATGAAGACCATCAC-3' & \multirow[t]{2}{*}{$171(24)$} & \multirow[t]{2}{*}{ NM 001050} \\
\hline SSTR 2A (reverse) & 5'-TGAACTGATTGATGCCATCCA-3' & & \\
\hline SSTR 3 (forward) & 5'-CTGGGTAACTCGCTTGGTCATCTA-3' & \multirow[t]{2}{*}{$86(24)$} & \multirow[t]{2}{*}{ NM 001051} \\
\hline SSTR 3 (reverse) & 5'-AGCGCCAGGTTGAGGATGTA-3' & & \\
\hline SSTR 4 (forward) & 5'-ATCTTCGCAGACACCAGACC-3' & \multirow[t]{2}{*}{$321(24)$} & \multirow[t]{2}{*}{ NM 001052} \\
\hline SSTR 4 (reverse) & 5'-ATCAAGGCTGGTCACGACGA-3' & & \\
\hline SSTR 5 (forward) & 5'-GTGACAACAGGACGCTGGT-3' & \multirow[t]{2}{*}{$156(25)$} & \multirow[t]{2}{*}{ NM 001053} \\
\hline SSTR 5 (reverse) & 5'-TGGTGACGGTCTTCATCTTG-3' & & \\
\hline HPRT (forward) & 5'-TGCTTTCCTTGGTCAGGCAGTAT-3' & \multirow[t]{2}{*}{$109(24)$} & \multirow[t]{2}{*}{ NM 000194} \\
\hline HPRT (reverse) & 5'-TCAAATCCAACAAAGTCTGGCTTATATC-3' & & \\
\hline
\end{tabular}

of them. Of the 9 non-functioning tumors, 5 were positive for SSTR $5(55.5 \%)$ with at least moderate staining intensity (score $\geq 2.00$ ), while 4 of the 9 expressed SSTR 2B (44.4\%), 3 of the 9 expressed SSTR 2A and 3 (33.3\%) (Fig. 1), and 2 of the 9 expressed SSTR $1(22.2 \%)$ with the same staining score (Table II). Positive SSTR 5 gene expression with a value of $\geq 1.000$ was observed in $75 \%$ of tumors; SSTR 2 and 3 mRNAs were observed in 62.5\%, and SSTR 1 and 4 mRNA occurred in $50 \%$ of tumors. An association was identified between positive SSTR $2(\mathrm{~A}+\mathrm{B})$ and SSTR 5 staining and high receptor mRNA expression (patient no. 6). In the case of patients no. 2 and 9, this association was with SSTR 5, and in patient no. 10 it was with SSTR 1, $2(\mathrm{~A}+\mathrm{B})$ and 3 (Table II). Another association was observed between low receptor protein expression and a low level of respective receptor mRNA (patient no. 1, for SSTR 1 and 4; patients no. 2 and 9, SSTR 1-4; patient no. 14, SSTR 1-5). Compatibility (both results positive or negative) between IHC and PCR methods was detected for SSTR 1 and 2 in $62.5 \%$ of the samples. Fifty percent of patients demonstrated compatibility for both SSTR 4 and 5 subtypes, and 37.5\% for SSTR 3. Finally, a high expression of mRNA and lack or weak receptor subtype levels were observed in patients no. 5 and 7 (for SSTR 1-5), patient no. 6 for SSTR 1, 3 and 4, and patient no. 10 for SSTR 4 and 5.

A similar analysis performed on 6 samples from hormonally-active adrenal adenomas revealed SSTR 1 expression in 5 (83.3\%) (Fig. 2), and SSTR 5 expression in 4 samples $(66.6 \%)$ (Table III). The SSTR 2B subtype was detected in 3 out of 6 adenomas $(50.0 \%)$ and SSTR $2 \mathrm{~A}$ and 3 , in 2 out of 6 tumors $(33.3 \%)$. In $66.6 \%$ of the sections, SSTR 5 mRNA was observed. The mRNA of the remaining subtypes was equally distributed in $50 \%$ of the samples. A concordance between high SSTR protein expression and a high level of corresponding mRNA was observed in patients no. 4 (SSTR 1-3 and 5), 8 (SSTR 1, 2 and 5), 11 (SSTR 5) and 15 (SSTR 2). For the following patients, an agreement between low levels of receptor protein and mRNA detection was observed: Patients no. 11 (SSTR 2-4), 12 (SSTR 2 and 4) and 13 (SSTR 2-5). Total compatibility of both methods was detected for SSTR 2

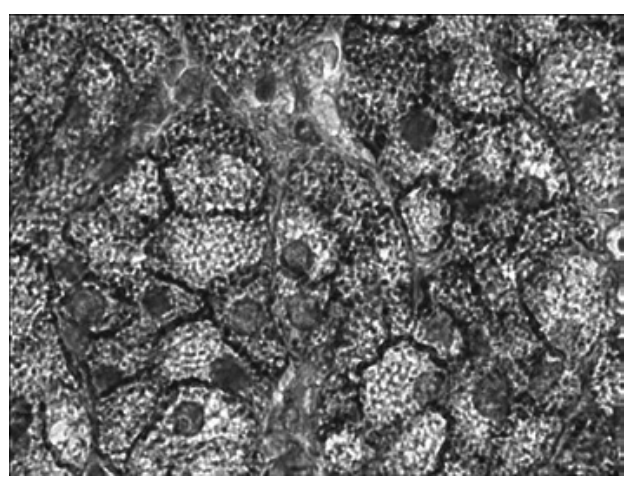

Figure 1. Expression of SSTR 2A in non-functioning adrenocortical adenoma (patient no. 10). Immunohistochemical reaction revealed strong immunostaining with membranous and cytoplasmic localization (magnification, $\mathrm{x} 400)$.

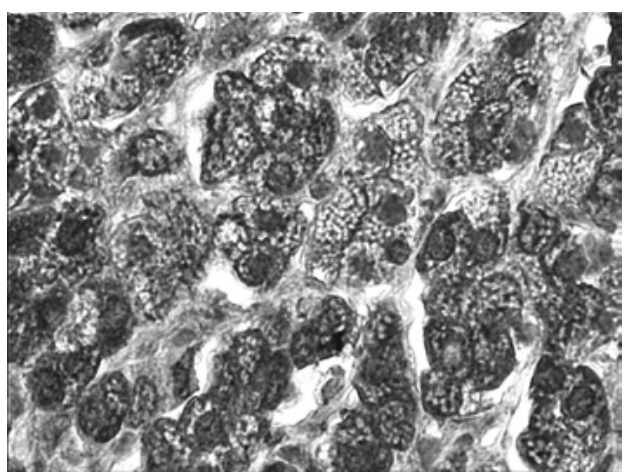

Figure 2. Expression of SSTR 1 in functionally active adrenocortical adenoma (patient no. 4). Immunohistochemical reaction revealed strong immunostaining with cytoplasmic localization (magnification, $x 400$ ).

(100\%). The results for SSTR 5 were compatible in $66.6 \%$ of samples for SSTR 3 and in 50\% for SSTR 4. The lowest compatibility was observed for SSTR 1 (33.3\%). Lastly, high receptor mRNA expression and lack of or weak receptor subtypes protein levels were detected in patients no. 4 (SSTR 4) and 8 (SSTR 3 and 4). 


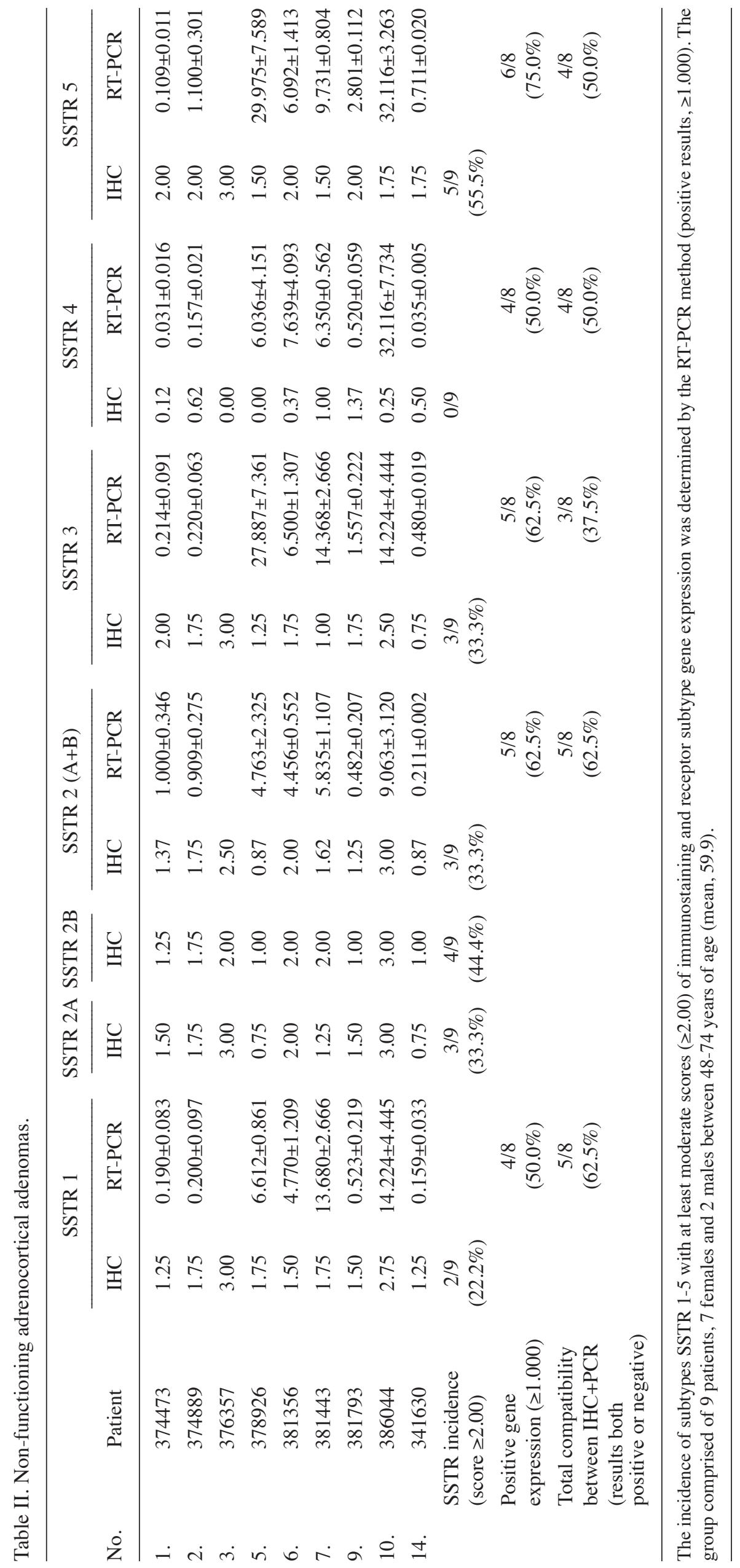




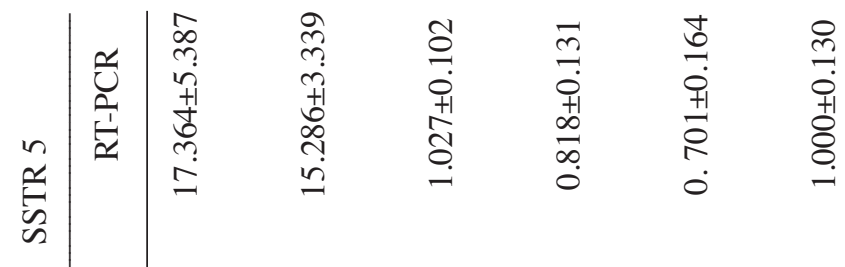

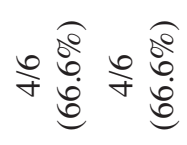

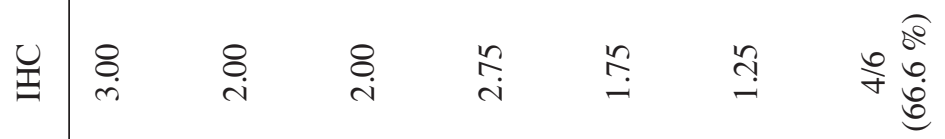

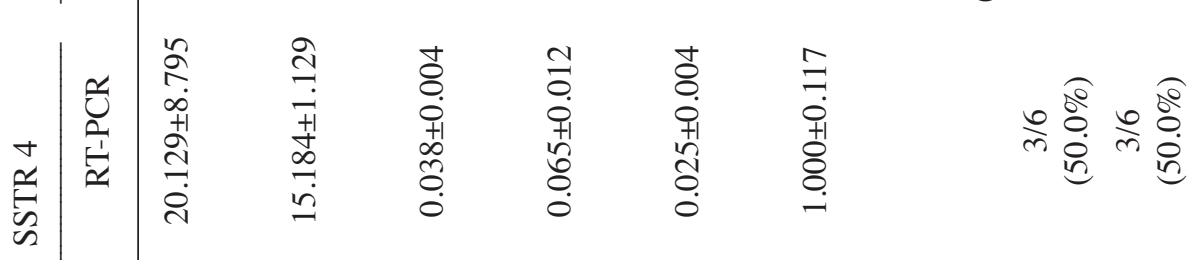

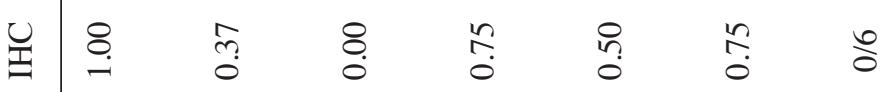

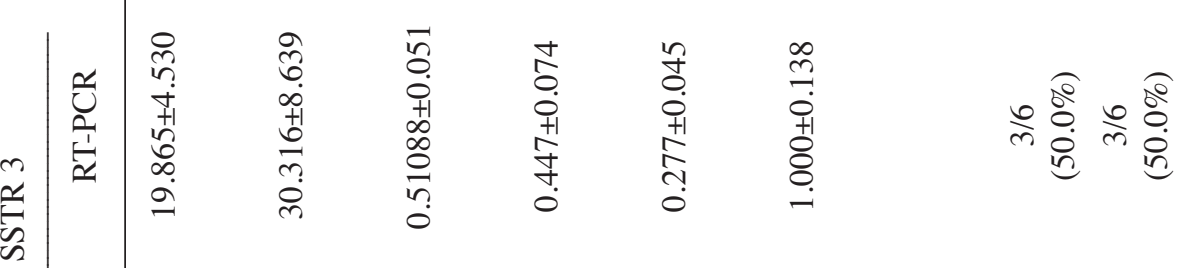

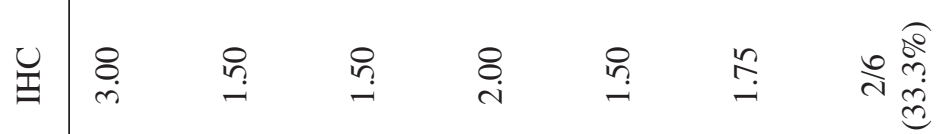

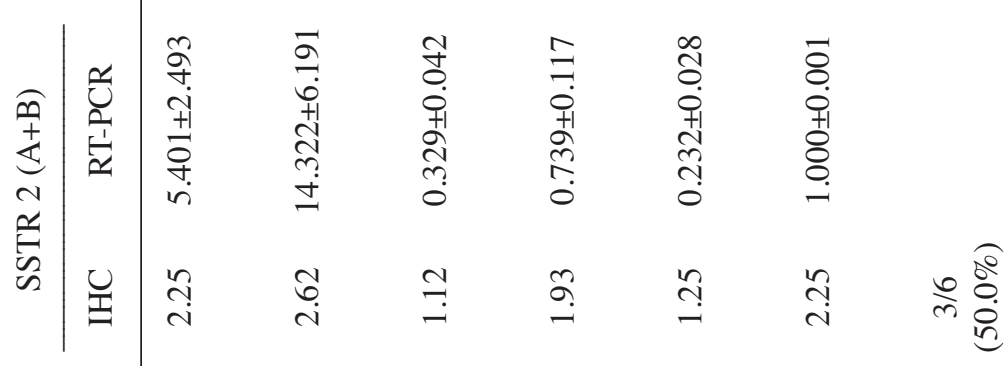

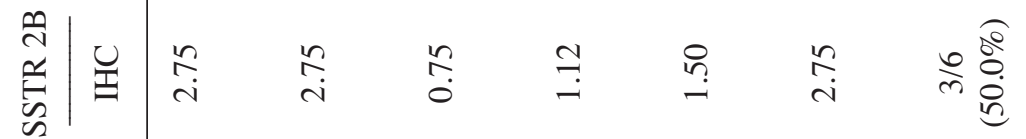

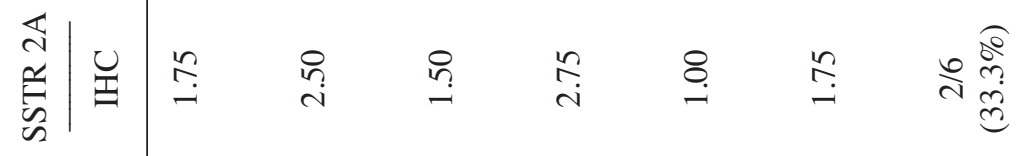

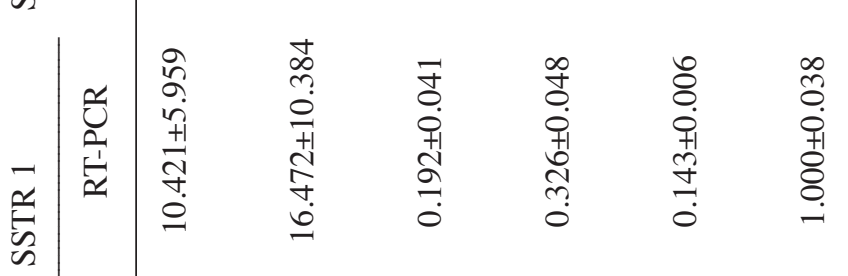

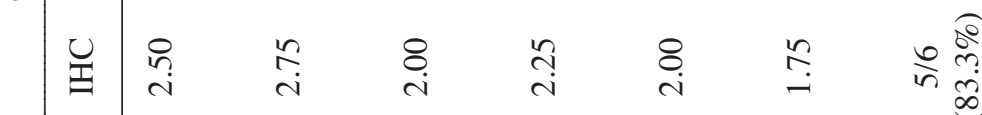

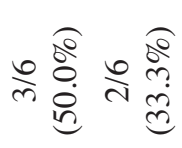

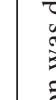

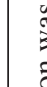

离 


\section{Discussion}

It is difficult to make an unequivocal statement regarding the differences between non-functioning and functionally active adenomas. However, certain conclusions concerning the relationship between tumor functionality and SSTR subtype expression can be drawn. In non-functioning tumors, SSTR 5 is the most frequently expressed SSTR subtype (55.5\%), whereas SSTR 1 was detected in $22.2 \%$. The reverse results were obtained for hormonally active adrenal cortex adenomas: SSTR 1 was the most frequent $(83.3 \%$ ) and SSTR 5 was observed in $66.6 \%$ of the samples. Also, in the case of SSTR 2B, higher immunopositivity in functioning adrenal adenomas occurred (44.4 vs. $50 \%$ ).

Notably, the immunopositivities of SSTR 1, 5 and 2B in the active adenomas were higher than in those without functionality, which raises the question of whether the hormonal activity of adenomas had an effect on SSTR expression. There were no differences observed for SSTR 2A and 3: they were equally detected in $33.3 \%$ of samples in both groups. No SSTR 4-positive staining with strong or moderate intensity occurred in any group. In our previous immunohistochemical study concerning SSTR subtype expression in adrenal gland tumors (22), 100\% expression of SSTR 1 and 5 with the same score (moderate and strong) was observed in adrenocortical adenomas. SSTR 2A with this score was detected in 9 out of 11 samples (81.8\%) and SSTR 3 in 10 out of 11 samples (90.9\%). Unfortunately, in this study the investigated tumors were not differentiated with regard to their functionality. The localization of the receptor protein was found to be both cytoplasmic and membranous, as well as a mixture of the two, independent of the functional activity of the investigated adenomas. The character of hormonal activity did not reflect the cellular distribution of SSTR subtypes.

Our results are compatible with those reported by previous authors, where differential distribution of SSTR subtypes in various adrenocortical adenomas was detected either by IHC $(9,11)$ or by PCR $(10,26)$. Reubi et al $(20)$, noted that a high level of endogenous somatostatin mRNA corresponds to cytoplasmic SSTR 2A staining, whereas plasma membranous staining was mostly observed in tumors lacking SST mRNA. In our samples, there was no specific data regarding the autocrine activity of endogenous SST, but certain observations may still be made. The specimens with primarily membranous receptor protein localization and lack of mRNA (low PCR score), (patients no. 2, 9, 11, 12,13 and 14) belonged to hormonally non-active and to functioning adenomas. Analogically, cytoplasmic receptor distribution and high expression of mRNA (patients no. 4, 5, 7 and 8) were observed in both categories of adrenocortical adenomas.

As can be observed, our results taken from adrenocortical adenomas confirm that receptor subtype gene expression determined by RT-PCR is not always synchronized with the receptor protein expression values estimated by IHC. In the present study, the highest (100\%) compatibility for both methods occurred only for SSTR 2 in functionally active adrenocortical adenomas. A lower result was obtained for SSTR 5 (66.6\%). In the group of non-active tumors, the highest agreement for IHC and PCR methods was demonstrated equally for SSTR 1 and 2 (62.5\%). For both SSTR 4 and 5 subtypes, this agreement was detected in $50 \%$ of patients. Thus, despite the presence of receptor mRNA, there were cases in which the respective receptor proteins were not detectable. Messenger RNA detection alone is not sufficient to prejudge the presence of the receptor protein, which is the molecular target for SST and its analogs. Our findings are in concordance with earlier statements of Reubi et al (20) and Pawlikowski (27). This may also confirm the thesis that a post-transcriptional defect or modification could occur after gene expression, causing the protein translation to be inhibited (19). One alternative explanation is that the quantity of SSTR proteins is below the detection limit, despite their expression on the cell surface. Another is that the detection methods used may have different sensitivities. The PCR technique is very sensitive and may overestimate the actual mRNA score and give false positive results due to expression of SSTRs in structures, such as the vascular endothelium or tumor infiltrating immune cells $(27,28)$. The false results may also be due to the presence of adrenomedullar cells included in the adrenal cortex adenomas visible in our slides. It could also be possible that the coexpression of several SSTR subtypes in one tumor leads to their heterodimerization and, in consequence, their activity is altered. Such a situation was observed by other authors $(8,29,30)$ in the cases of SSTR 2A and 3. Finally, sample fixation and processing or other associated technical issues may have had an effect.

\section{Acknowledgements}

The authors would like to thank Ms. Maria Jaranowska, Ms. Anna Opłatowska and Mr. Jacek Świętosławski for the skillful technical assistance, and Mr. Edward Lowczowski, who is a native English speaker, for proofreading of the text.

\section{References}

1. Koch CHA, Pacak K and Chrousos G: Genetic endocrine disease. The molecular pathogenesis of hereditary and sporadic adrenocortical and adrenomedullary tumors. J Clin Endocrinol Metab 87: 5367-5384, 2002.

2. Patalano A, Brancato V and Mantero F: Adrenocortical cancer treatment. Horm Res 71 (Suppl 1): 99-104, 2009.

3. Szabó PM, Wiener Z, Tömböl Z, et al: Differences in the expression of histamine-related genes and proteins in normal human adrenal cortex and adrenocortical tumors. Virchows Arch 455: 133-142, 2009.

4. Aquilera G, Parker DS and Catt KJ: Characterisation of somatostatin receptors in the rat adrenal glomerulosa zone. Endocr 111: 1376-1383, 1982.

5. Maurer R and Reubi JC: Somatostatin receptors in the adrenal. Mol Cell Endocrinol 45: 81-90, 1986.

6. Pisarek $\mathrm{H}$ and Pawlikowski M: Immunohistochemical localization of the somatostatin receptor subtype $2 \mathrm{~A}$ in the rat adrenal gland. Folia Histochem Cytobiol 40: 127-130, 2002.

7. Epelbaum J, Bertherat J, Prevost G, et al: Molecular and pharmacological characterization of somatostatin receptor subtypes in adrenal, extraadrenal, and malignant pheochromocytomas. J Clin Endocrinol Metab 80: 1837-1844, 1995.

8. Mundschenk J, Unger N, Schulz S, Holt V, Schulz S, Steinke R and Lehnert H: Somatostatin receptor subtypes in human pheochromocytoma: subcellular expression pattern and functional relevance for octreotide scintigraphy. J Clin Endocrinol Metab 88: 5150-5157, 2003.

9. Unger N, Serdiuk I, Sheu SY, et al: Immunohistochemical determination of somatostatin receptor subtypes 1,2A, 3, 4 and 5 in various adrenal tumors. Endocr Res 30: 931-934, 2004.

10. Ueberberg B, Tourne H, Redman A, Walz MK, Schmid KW, Mann K and Petersenn S: Differential expression of the human somatostatin receptor subtypes SST1 to SST5 in various adrenal tumors and normal adrenal gland. Horm Metab Res 37: 722-728, 2005. 
11. Unger N, Serdiuk I, Sheu SY, et al: Immunohistochemical localization of somatostatin receptor subtypes in benign and malignant adrenal tumours. Clin Endocrinol 68: 850-857, 2008.

12. Schally AV: Oncological applications of somatostatin analogues. Cancer Res 48: 6977-6985, 1988.

13. Pawlikowski M, Kunert-Radek J and Stępień H: Somatostatin - an antiproliferative hormone. In: Progress in Neuropeptide Research. Dohler KD and Pawlikowski M (eds). Birkhauser Verlag, Basel, pp. 3-12, 1989

14. Lamberts SW, Krenning EP and Reubi JC: The role of somatostatin and its analogs in the diagnosis and treatment of tumors. Endocrine Rev 12: 450-482, 1991 .

15. Mełeń-Mucha G, Winczyk K and Pawlikowski M: Somatostatin analogue octreotide and melatonin inhibit bromodeoxyuridine incorporation into cell nuclei and enhance apoptosis in the transplantable murine colon 38 cancer. Anticancer Res 18: 3615-3620, 1998.

16. De Herder WW and Lamberts SW: Somatostatin and somatostatin analogues: diagnostic and therapeutic uses. Curr Opin Oncol 14: 53-57, 2002.

17. Voltering EA: Development of targeted somatostatin-based antiangiogenic therapy: a review and future perspectives. Cancer Biother Radiopharm 18: 601-609, 2003.

18. Hu C, Yi C and Hao Z: The effect of somatostatin and SSTR 3 on proliferation and apoptosis of gastric cancer cells. Cancer Biol Ther 3: 726-730, 2004

19. Fischer WE, Doran TA, Muscarella P II, Boros L, Ellison CH and Schirmer WJ: Expression of somatostatin receptor subtypes 1-5 genes in human pancreatic cancer. J Nat Cancer Inst 90: 322-324, 1998.

20. Reubi JC, Waser B, Liu Q, Laissue JA and Schonbrunn A: Subcellular distribution of somatostatin SST2A receptors in human tumors of the nervous and neuroendocrine systems: membranous versus intracellular location. J Clin Endocrinol Metab 85: 3882-3891, 2000.

21. Pisarek H, Stepień T, Kubiak R, Borkowska E and Pawlikowski M: Expression of somatostatin receptor subtypes in human thyroid tumors: the immunohistochemical and molecular biology (RT-PCR) investigation. Thyroid Res 2: 1, 2009.
22. Pisarek H, Stepień T, Kubiak R and Pawlikowski M: Somatostatin receptors in human adrenal gland tumors - immunohistochemical study. Folia Histochem Cytobiol 46: 345-351, 2008

23. Schulz S, Schulz ST, Schmitt J, et al: Immunocytochemical detection of somatostatin receptors SST1, SST2A and SST3 in paraffin-embedded breast cancer tissue using subtype-specific antibodies. Clin Cancer Res 4: 2047-2052, 1998.

24. Ferone D, Pivonello R, van Hagen M, et al: Quantitative and functional expression of somatostatin receptor subtypes in human thymocytes. Am J Physiol Endocrinol Metab 283: E1056-E1066, 2002.

25. De Sa SV, Correa-Giannella LM, Machado MC, et al: Somatostatin receptor subtype 5 (SSTR5) mRNA expression is related to histopathological features of cell proliferation in insulinomas. Endocr Relat Cancer 13: 69-78, 2006.

26. Van der Hoek J, Waaijers M, van Koetsveld PM, et al: Distinct functional properties of native somatostatin receptor subtype 5 compared with subtype 2 in the regulation of ACTH release by corticotroph tumor cells. Am J Physiol Endocrinol Metab 289: E278-E287, 2005.

27. Pawlikowski M: Somatostatin receptors in human tumors in vitro studies. In: Somatostatin Analogs in Diagnostics and Therapy. Pawlikowski M (ed). Landes Bioscience, pp. 39-46, 2007.

28. Hofland LJ and Lamberts SWJ: The patholophysiological consequences of somatostatin receptor internalization and resistance. Endocr Rev 24: 28-47, 2003.

29. Pfeiffer M, Koch T, Schröder H, et al: Homo-and heterodimerization of somatostatin receptor subtypes. Inactivation of SST3 receptor function by heterodimerization with SST2A. J Biol Chem 276: 14027-14036, 2001.

30. Grant M, Alturaihi H, Jaquet P, Collier B and Kumar U: Cell growth inhibition and functioning of human somatostatin receptor type 2 are modulated by receptor heterodimerization. Mol Endocrinol 22: 2278-2292, 2008. 